\title{
Netizens' Responses towards the Covid-19 Pandemic Text: A Study of Speech Acts and Their Contents
}

\section{Laily Rahmatika}

Universitas Muhammadiyah Surakarta

Lailyrahmatika20@gmail.com

\section{Agus Budi Wahyudi}

Universitas Muhammadiyah Surakarta

Agus.B.Wahyudi@ums.ac.id

DOI: https://doi.org/10.18326/jopr.v2i2.177-200

Copyright (C) The Author (s)

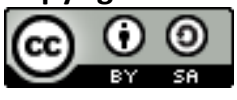

This work is licensed under a Creative Commons Attribution-ShareAlike 4.0 International License.

How to Cite: Rahmatika, L., \& Wahyudi, A. (2020). Netizens' Responses towards the Covid-19 Pandemic Text: A Study of Speech Acts and Their Contents. Journal of Pragmatics Research, 2(2), 178-201. doi:https://doi.org/10.18326/jopr.v2i2.178-201

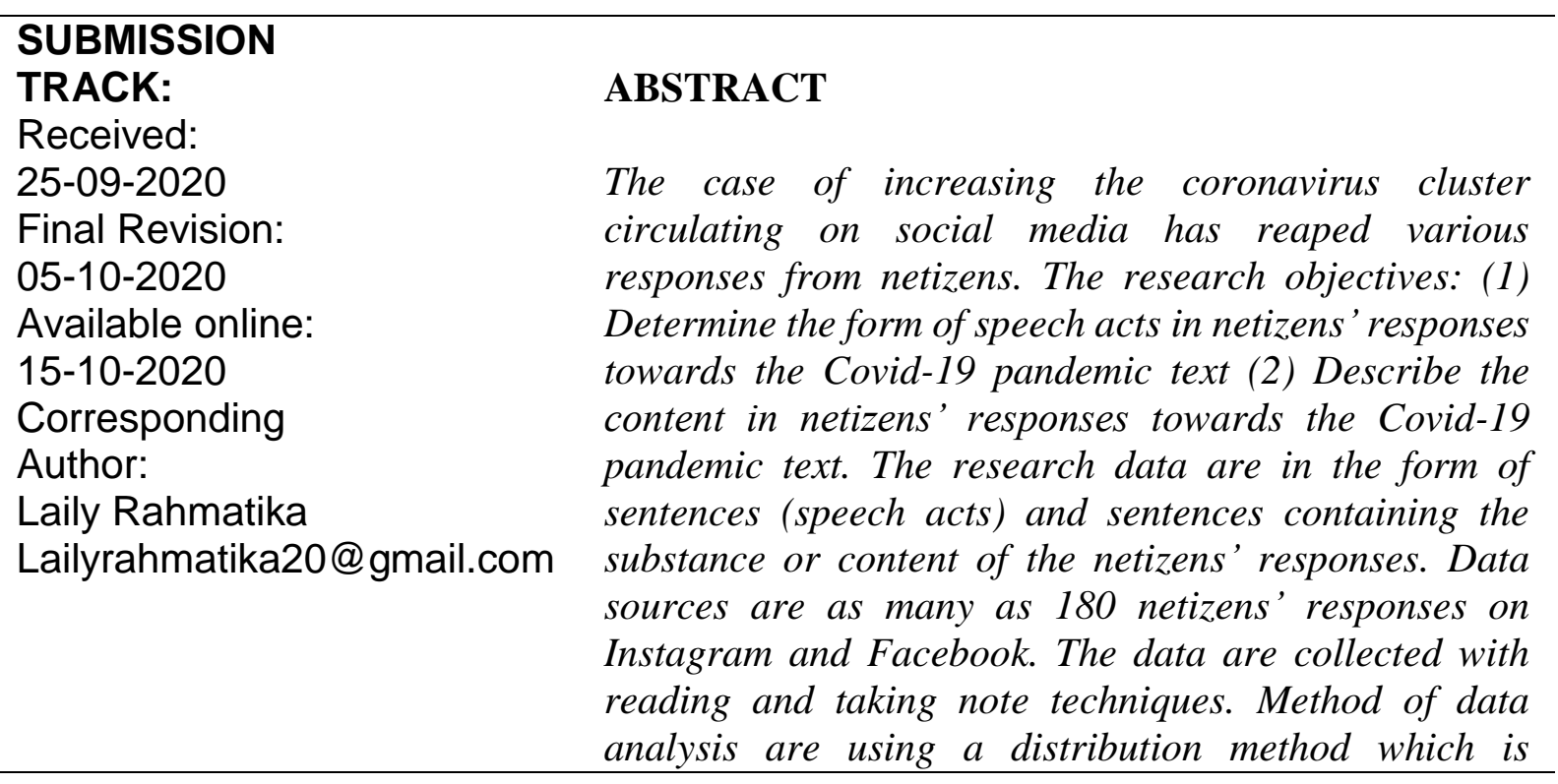


dividing the elements directly and the equivalent method with pragmatic techniques. The results: First, speech acts in netizens' responses as locutionary act, illocutionary acts, and perlocutionary act. Second, the content responses from netizens. $i$. optimistic ii. pessimistic iii. neutral.

Keywords: Netizens Response, Covid-19, Speech act, Content

\section{INTRODUCTION}

The coronavirus (Covid-19) has spread throughout the world, one of the countries is Indonesia as a global pandemic. In this 7 month period, cases in Indonesia on September 20, 2020, recorded 244,676 positive infections Covid-19 with the addition of 3,989 new cases reduced by the number of recovered patients reaching 177,327 people and cases of death reaching 9,553 people (Fanani, 2020). The increase in the number of positive cases of the coronavirus is caused by several factors, namely the massive inspection tests, the easing of large-scale social restrictions (PSBB), and not complying with the health protocol Covid-19.

According to Deni Kurniadi as the Epidemilog from Padjajaran University (in Lumbanrau, 2020), the cause of the increase in positive cases of Covid-19 in Indonesia is due to government regulations in implementing socialization that do not have a real, planned, measurable and evaluable program. To reduce the number of positive cases of Covid-19, various accounts on social media share information regarding the handling of the coronavirus, the development of the number of infected cases, and cases that have occurred through government and private accounts.

The existence of social media, netizens make it easy to communicate directly in the form of commenting on the information presented in the informant's account. The presence of social media provides freedom for netizens to express, interact, and communicate (Inderasari et al., 2019). The occurrence of interaction and communication in social media is not time-bound, everyone can be actively involved in it (Watie, 2011). This condition makes each individual have the opportunity to access various information.

In this case, the development of Covid-19 which is shared through accounts on Instagram and Facebook, both government and private, has reaped a response from the netizens. The amount of information and public discussion on social media about the coronavirus affects the formation of netizens' perceptions. This perception is formed through communication 
Vol. 2, No. 2, pp.177-200

E-ISSN: $2656-8020$

Website: http://e-journal.iainsalatiga.ac.id/index.php/jopr/index

between netizens in the comments column. For example: Quoted from the Instagram account @lambe turah regarding the circulation of the patient's family video is not accepting that the patient died due to being infected with the coronavirus (Covid-19) by the hospital. Meanwhile, the Indonesian Ministry of Health's Facebook account mentions the development of the number of cases infected with Covid-19 in Indonesia on September 20, 2020, reaching 244,676 cases with 177,327 people recovering, while 9,553 people died.

These facts are cases that create an atmosphere of life wrapped in anxiety, confusion, and fear caused by the development of the coronavirus (Covid-19) bringing up to various expressions. During the pandemic, Optimistic, pessimistic, and neutral content expressions are confirmed that they are repeatedly used when communicating.

This research is in line with the research of Juwita \& Purnamasassri (2018), Widyawati \& Utomo (2020) and Khotimah (2019) regarding the substance of assertive speech acts which has a high presentation of illocutionary speech acts. Meanwhile, in Stambo \& Ramadhan's research (2019) illocutionary speech acts that uttered the most verbs were in the type of directive speech act in the Indonesian Peace Program.

Illocutionary speech acts in the research of Wahyuni, Retnowaty, \& Ratnawati (2018), Fakhriyah (2020), and Miranti (2013) have not touched on the problem of response content in social media. Sekarsany, Damaryanti, \& Suparman's (2020) research which focuses on 3 types of illocutionary speech acts, namely: assertive with stating, mentioning, suggesting, and being proud. Directive with ordering, ordering, prohibiting, and convincing. Expressive with apologies, say hello, and praise.

Surianti, Akhir, \& Nojeng (2019), the results regarding the media for delivering social messages in public service advertisements include representative speech with the verb inviting, say, and tell. Directive speech with the verb command, bill, and order. Expressive speech with verb congratulate. Commissive speech with verb threatening and offering. Declaration with verb prohibits.

Research on illocutionary speech acts was conducted by Meirisa, Rashid, \& Murtadho (2017) and Nasution \& Efrima (2019). The results consisted of four categories of illocutionary speech acts including assertive, directive, commissive, and expressive. Azizah (2020) examines the speech act of the caption on Ridwan Kamil's Instagram, which includes speech acts that 
focus on four utterances, namely: Directive ordering and giving advice, expressive illocution of thanks, assertive illocutionary showing, and commissive illocution offering.

The speech context of the coronavirus pandemic (Covid-19) is a new study, because previous studies have never existed. It is especially study on social media, namely Instagram and Facebook. There is a novelty in the context of the study. Wargnet as a language speaker who is responsive to the problems of life in Indonesian society. Therefore, there is something new in the lexical field, namely the emergence of new lexical forms.

Optimistic, pessimistic, and neutral lexical content are the same locus. The presence of a new lexical is with optimistic content as a positive response, for example: in the form of submitting to the data (23). Meanwhile, those is with pessimistic content as a negative response, for example: manifested distrust of the Covid-19 handling system. Furthermore, those is with neutral content as a response to impartiality, pay attention to data (24).

The study based on Saerle's theory is in line with Tarigan (2009: 45) and Prayitno (2017: 49) to analyze speech acts with the content of netizens is an illocutionary speech act theory. In accordance with the following understanding, speech acts as a speech whose function is to inform something or do something (Surianti et all, 2019). Speech act is categorized as three types of action which are manifested in the form of (1) locutionary acts as the act of something. (2) illocutionary acts as the act of doing something. (3) Perlocutionary acts of affecting someone.

Illocutionary speech acts include: representative with the speech of telling, stating, suggesting, demanding, boasting, and reporting. Directive with the speech of ordering, pleading, prohibiting, ordering, asking, and giving advice. Commissive with the speech of an oath, promising, and declaring commitment. Expressive with the speech of gratitude, congratulations, forgiveness, praise, blame, and express condolences. Declarative with the speech of dismissing, deciding, isolating, and dropping.

Issues studied: (1) What are the forms of speech acts in netizens' responses towards the pandemic Covid-19 text? (2) What is the content in netizens' responses towards the pandemic Covid-19 text? Research objectives: (1) Determine the form of speech acts in netizens' responses towards the pandemic Covid-19 text (2) Describe the content in netizens' responses towards the pandemic Covid-19 Text. 
Website: http://e-journal.iainsalatiga.ac.id/index.php/jopr/index

\section{RESEARCH METHOD}

The type of descriptive qualitative research. The research data are in the form of sentences (speech acts) and sentences containing the substance or content of the netizens' responses. Data sources are as many as 180 netizens' responses on Instagram and Facebook. The data are collected with reading and taking note techniques. Method of data analysis are using a distribution method which is dividing the elements directly and the equivalent method with pragmatic techniques (Sudaryanto, 2015). The results of presenting the analysis are in the form of descriptive explanations.

\section{RESULTS \& DISCUSSION}

\section{Netizens' Locutionary Acts towards the Covid-19 Pandemic}

Netizens' Responses towards Covid-19 with A Speech That Provided 'Information about the Swab Test'.

Look at the quote below.

Context of dr.tirta - 1. The price for the independent swab test was decided to be a max IDR 900,000 (previously on IG TV I shouted there was no top price, the previous price was 1.5-2.3 million, the price dropped slightly -.-) If the result is negative, it still pays independent. So the price IDR 900,000 is still an expensive for people whose salaries are regional minimum wage. Hopefully there will be a subsidy for people who are underpaid 2. There is another statement: Covid patient care is free and borne by the government (previously only covered only if via Covid referral, now all are free wherever the hospital is). There is something lacking: FREE SWAB FOR HIGH INFECTION AREAS IN 3T OF FOOD ASSISTANCE FOR SOME AREAS WITH MINUS ECONOMY* For free swab depends on THE DECISION OF EACH REGIONAL HEAD. NATIONAL BIG DATA improvements are needed. So that data can be real time and without delay 2 . There is no prejudice. Whether it is coincidence or not, there have been many changes and improvements in policy after we speak out. I don't want GR, which is all important for the goodness of the societies. 
(1) "Di daerah saya mulai ada swab gratis dok, tapi diprioritaskan untuk orang yang memiliki gejala atau ada penyakit bawaan. Belum tau benar apa tidaknya semoga terealisasikan." (In my area started to have a free swab, docter. But this is prioritized for people who have symptoms or have congenital diseases. I do not really know right or not, hopefully it will be realized)

Data (1) is in the form of declarative responses about the swab test. This information is conveyed as a response with current context or up to date events.

\section{Netizens 'Ask the Problem' of Covid-19 Regarding the Clarity of the Individual Who Was}

\section{Given the Vaccine.}

Context of kemenkes_ri - Hi \#Healthies. The government and several agencies are working hard to produce vaccines COVID-19, for this reason, there is no definitive drug or vaccine that can be found tackling COVID-19. The main thing remains disciplined apply health protocols to protect yourself and Yes, Healthies \# unified Against COVID19 \#disciplinepakaimasker \#alupakaimasker

(2) "Kalau vaksin sudah tersedia, kira2 siapa yg akan dapat duluan? Apakah sudah Ada rencana tindakan yg dibuat oleh Kementerian semisal penerapan daerah prioritas, mekanisme transportasi Dan cold chain-nya?"

(If the vaccine is available, who will get it first? Has there been an action plan made by the Ministry, such as the implementation of priority areas, transportation mechanisms and cold chains?)

Data (2) is in the form of introgative responses about vaccine clarity. Asking the problem is submitted in response to questions that have not yet found a clear answer.

\section{Netizens 'Order the Trut' Covid-19 Regarding the Problem of People Who Are Infected}

\section{Covid-19}

Context of dr.tirta - 3 months left for the election, guys. Do you still remember my suggestion on ig TV and podcasts about the death audit? There is information, if it is infected positive Covid, all costs are borne by the government. And about "data", death audit research is important so that in the future there are similar viruses, we can better handle them. Mr. @ganjar_pranowo and@kantorstafpresidenri give a response here. You can check here. That means there is a problem about "data", in essence I know: health workers are only the implementers of treating and educating patients. The data issue is not a matter for health workers, but for the hospital and health and local health services 
Website: http://e-journal.iainsalatiga.ac.id/index.php/jopr/index

https://www.infopresiden.com/2020/10/moeldoko-rumah-sakit-jangan-sall.html?m=1 https://regional.kompas.com/read/2020/10/01/19033991/bertemu-ganjar-moeldoko-jangan$\underline{\text { sall-kematian-selalu-karena-covid-19 }}$

I just share. Don't get tired again. The information have a certain quality. . KSP. Don't get bored with me :p

(3) "Bongkaarrr terus dok, bekerja lah secara jujur buat yg lain..jangan memanfaatkan peluang yg ada!!"”

(Keeping on take a part, docter. Work honestly for others. Don't take advantage of the opportunities that exist !!)

Data (3) is in the form of imperative responses about people who are infected Covid-19. Ordering the truth is form reveals a hidden truth.

Locutionary speech acts are responses by citizens in the form of declarative by providing swab test information, interrogative by asking the clarity of vaccine administration, and imperative by asking the truth of the infected community toward Covid-19.

\section{Netizens' Illocutionary Acts toward the Covid-19 Pandemic}

Illocutionary acts are categorized based on their form representative, directive, commissive, expressive, and declarative responses.

\section{Representative Responses}

There are five netizen responses toward Covid-19 which are representative types.

\section{Expressing Opinion}

Context of dr.tirta - Sit on the floor first. Tuk tang tuk tang tuk tang.

(4) "Mohon imbangi dikit postingannya sama orang orang yang pada g bisa makan mau byar kontrakan g bisa pusing mikirin kluarga dll.... biar imbang aj ini mah kan dokter udh jd publik figur atau infuencer ktanya..."

(Please be balance a little posting with people who unable to eat which cannot to rent rented, getting dizzy thinking about family, etc. So that this is balanced, doctor is already a public figure or an infuser, he said) 
Data (4) as representative responses TT Illocutionary states expressing opinion. The marker of TT above is marked by "g bisa makan". In this context, $\mathrm{O} 1$ expressed opinion to $\mathrm{O} 2$, because $\mathrm{O} 1$ wanted a balance of $\mathrm{O} 2$ posts between the affected communities including street vendors, online vehicles, motorbike taxis, public transportation drivers, street sweepers, and workers who were dismissed and rear guard including doctors, nurses, and medical personnel. TT above in the data with the markers "g bisa makan" is a sympathy for O1. While, the word "doctor" in data (4) is a form of greeting based on social status.

\section{Notifying Conditions}

Context of lambe_turah - Jakarta is Large-scale Social Restrictions... The Governor of DKI Jakarta, Anies Baswedan re-implements Large-scale Social Restrictions (PSBB) as an emergency brake measure related to the pandemic coronavirus (Covid-19).

(5) "Ayolah masyarakat Indonesia,jangan sok sok an gak percaya sama covid-19 ini,virus ini beneran ada!,mau sampai kapan kita hidup kayak gini?,ayolah teman" semua patuhi protokol kesehatan."

(Come on, Indonesian people don't be pretentious not believe in Covid-19, this virus comes really exists! How long do we want to live like this? Come on all friends obey health protocols.)

Data (5) as representative responses TT Illocutionary states notifying conditions. The marker of TT above is marked with "beneran ada". In this context, O1 informed O2, because some people did not believe in the coronavirus (Covid-19), even they did not comply with health protocols in carrying out their daily activities. TT in the data above with the marker "beneran $a d a^{\prime \prime}$ is a statement to convince netizens to take precautions in the midst of a coronavirus outbreak that actually exists.

\section{Providing Suggestions}

Context of Kemenkes_ri - Hi \#Healthies. My mask protects you, your mask protects me. These are messages from Athletes your favorite so that we can stop the spread of COVID-19 together with \#Donotslackoff \#AlwaysUseMask. Let's be disciplined \#UniteAgainstCovid19 \#AlwaysUseMask. 
Vol. 2, No. 2, pp.177-200

E-ISSN: $2656-8020$

Website: http://e-journal.iainsalatiga.ac.id/index.php/jopr/index

(6) "Kepada Kementrian Kesehatan RI, Sebaiknnya restoran di tutup untuk makan di tempat (Sementara) Covid19 sudah meningkat bagimana ? Di luar saja sudah banyak yang berkumpul menjadi Cluster Covid!, Sekarang apakah Rumah sakit Bisa menanggung lebih banyak pasien Covid? Lebih bijaksana untuk di Stop Sekarang sebelum Covid menembus lebih dari 200,000 kasus ! Terima Kasih, semoga di ambil Keputusannya, Safe Our Country, \#SafeIndonesiasebelumcovidmelonjaklbh200k"

(To the Indonesian Ministry of Health, it is better if restaurants are closed to eat at places (Temporary) How Covid19 has increased? Outside, many people have gathered to become the Covid Cluster! Now, can the hospital cover more Covid patients? It's wiser to stop now before Covid penetrates more than 200,000 cases! Thank you, hopefully the decision will be taken, Safe Our Country, \# SafeIndonesiasebelumcovid jumped to 200k)

Data (6) as representative responses TT Illocutionary states providing suggestions. The marker of TT above is marked with "Sebaiknnya". In this context, O1 provides O2 advice, because the cluster of positive cases infected with the coronavirus (Covid-19) is increasing per day. TT in the data above is marked as "Sebaiknnya" as providing suggestions to the government in reducing the increase in the number of cases and stopping the transmission of Covid-19 by always wearing a mask, keeping your distance, and not crowding the world.

\section{Demanding}

Context kemenkes_ri - Good morning \#Healthies! The spirit of starting today's activities, don't forget to always wear your mask wherever and whenever you are. Because each of us can become a hero by protecting others. Take care of your health, cleanliness and the information you get. Greetings healthy! \#fashionnovation.

(7) "Para pejabat pada pakai masker scuba sedangkan masyarakat dilarang pakai masker scuba? Kalau nyuruh masyarakat ganti jangan pakai scuba tuncukin dulu atau beri contoh."

(Officials wear scuba masks. While, are societies prohibited from wearing scuba masks? If you tell the community to replace, don't use scuba. Show first or give an example.)

Data (7) as representative responses TT Illocutionary states demanding. The marker of TT above is marked with “dilarang”. In this context, O1 demands O2, because the use of scuba masks that are not allowed to be used by the government but are still used in use, one of which is a photo in the context post above in running sports that still use scuba masks. TT in data 
above with the marker "dilarang" as a form of netizens' demanding to the government on the policy of prohibiting the use of scuba masks.

\section{Suspecting}

Context indotoday - The best president in the world, in dealing with the corona outbreak. You agree, Jokowi invites a number of artists to the palace!

(8) "Artis kan lebih go publik... Mreka diminta untuk beri edukasi/ semangat.. buat kita.. maksudnya artis jd media yg paling mudah.. jd jembatan info positif penanganan covid.. kalo masalah bukan dokter.. kan mentri kes bisa di minta infonya."

(Artists go public more. They are requested to give education / enthusiasm for us. It means artists are the easiest media. So it is a bridge of positive information about Covid handling if the problem is not a doctor. The minister of health can be ask for the information ..)

Data (8) as representative responses TT Illocutionary states suspecting. The marker if TT above is marked with "diminta". In this context, $\mathrm{O} 1$ suspects $\mathrm{O} 2$, because several celebrities have been invited to the palace to help in the government's campaign or socialization in handling Covid-19 for the Indonesian people. TT in the data above is marked with "diminta" as an effort to educate the public to make them aware of the importance of using masks in protecting themselves in the midst of a pandemic.

\section{Directive Responses}

There are two netizen responses toward Covid-19 which are directive types.

\section{Inviting}

Context of Ministry of Health RI - Hi \#Healthies. In this pandemic, let's prevent transmission of COVID-19 at the joint office. Keep up the health protocol. \# withCOVID19

(9) "Memaksimal mungkin memutus mata rantai virus bahkan sampai geram menangani pandemi ini...Tinggal kitanya sebagai masyarakat mari kita bantu pemerintah kita. Jangan saling menyalahkan! Dimulai dari diri kita sendiri jaga kesehatan.'

(As much as possible to cut the chain of the virus, even it is to the point of being furious about handling this pandemic. It remains us as a society. Let's help our government. Don't blame each other! Starting from ourselves take care of our health.) 
Data (9) as directive responses TT Illocutionary states inviting. The marker of TT above is marked with "bantu". In this context, O1 invites $\mathrm{O} 2$, because it is a way to assist the government in breaking the chain of spreading the coronavirus. TT in the data above is marked with "bantu" as an effort to care for netizens in handling the Covid-19 pandemic by providing a statement by maintaining health and complying with protocols.

\section{Requesting}

Context of aniesbaswedan - COVID-19 Social Assistance Phase 7 at @ dkijakarta. Since last Tuesday (15/9), the DKI Jakarta Provincial Government has synergized with the Indonesian Ministry of Social Affairs to begin distributing Phase 7 social assistance (Bansos) to homes of 2.4 million poor and vulnerable families affected by COVID-19, both DKI KTP or KTP Non DKI residing in Jakarta.

(10) "Pak anis.. Boleh usul gak... Jangan sarden terus tapi ganti sama kornet... Sekali kali makan daging pak..."

(Mr. Anis, Can I suggest... Don't keep sardines but it replaces with the corned beef ... Once, eat meat sir ...)

Data (10) as directive responses TT Illocutionary states requesting. The marker of TT above is marked with "ganti". In this context, $\mathrm{O} 1$ asks $\mathrm{O} 2$, because netizens want to get help with things that make their needs met. TT in the data above is marked with "ganti" as a form of request for a new item of social assistance distribution.

\section{Commissive Responses}

There is netizen response towards Covid-19 which is commissive types.

\section{Giving appoinment}

Context of ganjar_purnowo - Kalau ada saudara atau temenmu yg tidak pakai masker, gimana cara kamu mengingatkan? Pernah dibantah atau disepelekan?

Context of ganjar_purnowo - If there is sibling or friend who does not wear a mask, how do you remind him? Have you been denied or ignored? 
(11) "Demi memutus rantai covid 19 saya tetep pake masker pak walaupun temen2 saya bilang ga baik buat kesehatan karna kekurangan oksigen dan malah menghirup co2 dari napas sendiri."

(For the sake of breaking the Covid-19 chain, I still use a mask, sir, even though my friends say it's not good for health because it lacks oxygen and instead inhales $\mathrm{CO} 2$ from my own breath.)

Data (11) sebagai TTI komisif menyatakan pemberian janji. Penanda TT diatas ditandai dengan "saya tetep pake masker". Dalam konteks ini, O1 memberikan janji ke O2, karena tujuannya untuk memutus rantai penularan kluster covid-19 yaitu dengan selalu memaki masker dimanapu, kapanpun berada. TT pada data di atas dengan penanda "saya tetep pake masker" sebagai bentuk mematuhi protokol kesehatan.

\section{Expressive Responses}

There are four netizen responses towards Covid-19 which are expressive types.

\section{Providing Support}

Context of the Indonesian Ministry of Health - Indonesia is Committed to Increase Health Innovation in Handling COVID-19.

(12) "Tetap semangat dan terus berpikir positif semoga pandemi ini cepat berakhir... terutama buat para medis pengorbanan kalian begitu luar biasa dan berjasa berada di garda paling depan semoga allah melindungi kalian Amin."

(Keep it up and keep thinking positively, hopefully this pandemic will end quickly. Especially it is for the medics, your sacrifices are so extraordinary and are credited with being at the forefront. Hopefully Allah will protect you Amen.)

Data (12) as expressive responses TT Illocutionary states providing support. The marker of TT above is marked with "semoga pandemi ini cepat berakhir" In this context, O1 provides O2 support, because middle medical services have made sacrifices in helping to recover patients even with simple facilities. TT in the data above is marked "semoga pandemi ini cepat berakhir" as a form of positive support to continue to survive in sacrificing services during the Covid-19 pandemic until the end of the pandemic.

\section{Saying Thank You}


Vol. 2, No. 2, pp.177-200

E-ISSN: $2656-8020$

Website: http://e-journal.iainsalatiga.ac.id/index.php/jopr/index

Context of aniesbaswedan - Jakarta against Covid from @dkijakarta Friends, we still have to struggle with this COVID-19. Follow the rules. Let's live a clean and healthy life, so that the people of Jakarta will be safe.

(13) "Temen ngaji sy mengucapkan terima kasih pak Anies ats perhatian Bapak tuk para pasien covid, teman sy sekeluraga yg skrg sedang di rawat di wisma atlet kemayoran, temen sy bilang dr kamar sampai pelayanan kesehatannya benar2 diutamakan, dan tidak lupa teman sy jg mendoakan bapak beserta jajaran dan para nakes agar selalu dilindungi oleh Allah SWT...Aamiin Yaa Robbal Alaamiin."

(My friend says thank you to Mr. Anies for his attention toward the Covid patients, my friends and family who are currently being cared for at Wisma Atlet the Kemayoran, my friend said that the room until the health service is prioritized, and don't forget my friends also pray for you and your ranks and health workers to always be protected by Allah SWT ... Aamiin Yaa Robbal Alaamiin.)

Data (13) as expressive responses TT Illocutionary states saying thank you. The matker of TT above is marked with "terima kasih". In this context, O1 thanks to O2, because O2's caring attitude towards Covid-19 patients was prioritized in terms of service. TT in the data above is marked "terima kasih" as a gratitude for the facilities provided in handling Covid-19.

\section{Expressing Concerned}

Context of kumparancom - Doctors provide various first aid when a corona patient is critical, one of which is Gamaras. Gamaras therapy is also undertaken by Loki - It , a corona patient in South Tangerang, is not his real name. In a day, Loki has to finish 13 bottles of Gamaras by infusion.

The price of 13 bottles of Gamaras consumed by Loki in a day can reach IDR 63,794,120. That means, one bottle of Gamaras is priced at IDR 4,907,240. This medicine is known to be made from healthy human blood plasma, where the antibody content in it can fight germs or disease

(14) "Kasian pasiennya, dah mikirin idup sama mati, harus mikirin juga biaya perawatannya."

(How Poor the patient, it already thought about life and death, it must also think about the cost of treatment also)

Data (14) as expressive responses TT Illocutionary states expressing concerned. The marker of TT above is marked with "kasian pasiennya". In this context O1 expresses O2's 
concern, because the price of drugs cannot be reached by all levels of society to get the same opportunity for help. TT in the data above with the marker "kasian pasiennya" as a form of public concern over.

\section{Criticizing}

Context kumparancom - Commissioner of the Indonesian Ombudsman @ alvinlie21 mentioned about the Ministry of Health, which is currently the largest corona cluster. According to Alvin, it should be @ kemenkes_ri can be a role model. This certainly affects the credibility of the agency

(15) "Presidennya buat aturan nggak jelas. begitupun juga mentrinya. mulai dari PSBB sampai PSBM. menurun nggak meningkat iya. suruh makan nasi kucing, minum jamu hingga kalung anti corona. Virus itu di teliti bukan buat bahan percobaan apalagi lelucon. Kerja Kerja Kerja jadi selogan, tapi kok gini hasilnya. coba minta penilaian dari masyarakat secara random. seberapa seriusnya pemerintah dalam penangan covid ini." (The president makes unclear rules, likewise his minister. Starting from PSBB to PSBM, it is decreasing. It is not increasing. It is asked to eat nasi kucing, drink herbs till anticorona necklaces. The virus was examined not for experimental materials moreover jokes. Work, Work, and Work are slogan, but how come this is the result. Try asking for a random assessment from the public. How serious the government is in handling this Covid.)

Data (21) as expressive responses TT Illocutionary states criticizing. The marker of TT above is marked with "aturan nggak jelas". In this context $\mathrm{O} 1$ criticizes $\mathrm{O} 2$, because the regulations in handling Covid-19 set by the government are encouraging and unclear. TT in the data above is marked with "aturan nggak jelas" as a decrease in the government's creativity in dealing with the Covid-19 pandemic.

\section{Declarative Responses}

There is netizen response towards Covid-19 which is declarative types.

\section{Convey the Truth}

Context kumparancom - Loki (not his real name), the corona patient who was treated in South Tangerang, was first admitted to the COVID-19 referral hospital on August 29. He, his wife, and their son contracted COVID-19. Loki and his wife were treated in the same hospital, while their son was treated in DKI Jakarta. "It turned out that Loki received a receipt from the hospital 
on 18 September. Their son was also given information that the hospital could receive replacement costs from the government. However, the patient must first pay the costs to the hospital and then to be refunded to the government. In total Loki's bill until 18 September was IDR 584,551,066.

(16) "Tante saya covid malah bayar pake asuransi kantor, aneh bgt dah sistem pemerintahan skrg, ga terbuka dan gajelasss."

(My aunt is infected with Covid paid for using office insurance, it's really strange that the current government system is not open minded and not clear.)

Data (16) as declarative responses TT Illocutionary states convey the truth. The marker of TT above is marked with "ga terbuka dan gajelas". In this context, O1 conveys the truth of $\mathrm{O} 2$, because government policies and hospital service techniques like this do not consider the quality, quality, cost efficiency and sustainability of Covid-19 patients. TT in the data above with the markers "ga terbuka dan gajelas" is the reality of policies and regulations that consider transparency in handling Covid-19.

Illocutionary speech acts are responses by citizens in the form of representative by expressing opinion, notifying conditions, providing suggestion, demanding, and suspect, directive by inviting and requesting, commissive by giving appointment, expressive by providing support, saying thank you, expressing concerned, criticizing, and declarative by convey the truth.

\section{Netizens' Perlocutionary Acts towards the Covid-19 Pandemic}

Illocutionary acts are categorized based on their form representative, directive, commissive, expressive, and declarative responses.

\section{Representative Responses}

\section{Express anxiety}

Context of dr.tirta - Who needs a job and need money. You can register. Just help spread out. Then get money. It is advantage. It is Very helpful. Don't pick me up ndaaaan! I am a good citizen. Just forgot to use drx king mirrors. Freedom of speech!!!!! 
(17) “Ketika omongan influencer lebih dipercaya dibanding yang berpengalaman." (When the influencer talk is more trusted than experienced people.)

Netizens mean in data (17) "personal anxiety" about the "Covid-19 education system". The Covid-19 education system IS entrusted to influencers so that health workers were underestimated. The effect is that the community does not respect these actions.

\section{Directive Response}

\section{Waiting for Clarity}

Context of dr.tirta - When an expert retreats, there is something. My Instagram posts are similar to professional statements regarding tracing and treatment tests. You can check it on the next slide, understand it. I have 4 posts today, the rest will be live part 4 tonight. Anyway, until now I'm still a volunteer for the national task force on behavior change :). My job is to educate without stop in the field anytime, anywhere. It is eternal bosqqqqqueeee.)

(18) "Di tunggu happy endingnya dok, dari drama covid ini. Selamat berjuang mewakili suara kami."

(Waiting for the happy ending, doctor, from this Covid drama. Good luck representing our voice.)

Netizens mean the data (18) "awaiting clarity on the end of the Covid-19 pandemic". When is the 'happy ending of the plague'? The effect is that the lives of netizens are uncomfortable, because they do not know where the disaster will end.

\section{Commissive Response}

\section{Committed}

Context of dr.tirta - Morning breakfast with meat, bosqueee. 7 months in the field, the evidence is in my brain. As long as I am alive, I will continue to share every day 10-14 posts that make you think. Instead of cultivating "the young who farm" but it finds catchy findings! A modern necklace, disclaimer: I AM JUST GOOGLE NEWS, LOTS, READ YOURSELF, CLEAR SOURCE - DON'T BE ANTI CRITICS! February was tourism influencer even though Covid is viral in the world July> anti-corona necklace. Does anyone know? How about the anti-corona necklace? Why don't you program hydroponic farming for young people? That's good during 
the pandemic September> Jakarta psbb again, positive cases break the record then, Indonesia's economy was decided to enter into recession.

(19) "Saya tidak pernah anti terhadap nakes, bagaimanapun Sama2 pejuang kehidupan, yg perlu dibasmi di Indonesia ini adalah birokrasi yang membingungkan rakyat, apalagi jika ada yg memanfaatkan situasi untuk memperkaya diri dengan dalih kesehatan adalah kejahatan yang nyata. Semangat dok."

(I've never been against health workers, however we are warrior's life, which needs to be eradicated in Indonesia this is a confusing bureaucracy of the people, especially if someone takes advantage of the situation to enrich themselves under the pretext of health is a real crime. Docter, spirit.)

Netizens means in the data (19) "not to blame the health workers" towards the anticorona necklace. The anti-corona necklace that is traded come from the bureaucracy instead of being certain that are concerned with the situation. The effect is that netizens has an issue with the bureaucratic system for handling Covid-19.

\section{Ekspressive Responses}

\section{Praying}

Context of indotoday - Doctors in West Sumatra built a laboratory to provide free swab testing services to the public. He is dr. Andani Eka Putra as the Head of the Diagnostic and Research Laboratory for Infectious Diseases, FK Andalas University. He is willing to spend his personal fund of IDR 850 million to build a laboratory for testing COVID-19 specimens. He called this for the independence of the nation and also for the benefit of the people.

(20) "Semoga yang penghasilan nya berlebih terketuk hatinya bisa ikut membantu membangun satu layanan gratis bagi warga tidak mampu ditiap kota indonesia seperti pak dokter aamiin."

(Hopefully those with excess income will knock their hearts out to help build a free service for underprivileged residents in every city of Indonesia, such as Dr.Aamiin.)

Wargenet means data (20) 'to say prayers for those who earn more. In effect, that person helps reduce problems to reduce the covid-19 cluster. 


\section{Suggestion}

Context of dr.tirta - Think it logically. If you check. If it's positive, just bear it. Negative pays for yourself. The complete check is MY IG TV. How you want to improve the testing feature. If the price is too expensive. It is only one solution: free swab for DIFFERENT areas. Most of the Covid 19 symptoms are mild or asymptomatic. Well. If there are no symptoms. He wants a test. Yes, doubt. Because if it's negative, it's not paid. In the end, the hospital is COVER THE SHORTCOMINGS if the patient can't pay. Hahaha if the hospital cover the shortcomings. Hospital employees are haunted or not? Think logic bro. Employees need to eat too, right? So what are they doing? Logic. . Health professional? Doctors are just executors, bro. How could this be that. We make strange voices just betting "license revoked" hahaha. Me? Yo just hurry up. Nothing to lose. You are only being pitted against each other by a "corrupt" system. If the hospital only bought a swab tool. And the managing doctor. Then who is the distributor of pcr swab that charges a high price? ? ? p hayoo who's hayoooo

(21) "Kita seharusnya bersyukur ada yang mau menyuarakan covid sebenarnya yang blakblakan gini tuh hebat banget Lo. Dok aku wongmu."

(We should be grateful that there are those who want to speak out about Covid, actually the one who is outspoken is really great. Doc I'm support you.)

Netizens intent on data (21) "suggest to reveal the truth" of the price of the swab test. Voiced about price inconvenience in the swab test where there is no price accuracy in the payment. The effect is that people are more open minded to the problems that occur.

\section{Declarative Response}

\section{Taking Issue}

Context of dr.tirta - Last for this morning, once again, I only share old news. FROM MY FEED, YOU WILL KNOW, IS THERE STRANGE WHETHER TO HANDLING COVID IN INDONESIA? HA HA HA Who made the findings, who hit whom :) "Geez, don't do anything with me, just a voice of the rabbel". You judge for yourself. I am just sharing the news in the morning, enjoy while having breakfast. We'll continue the fun discussion this afternoon. At 07.30 I live on TV ONE :) Someone asked me to talk about this on TV. That is. Cipeng gas gas is back bosque.

Like this ... for example the government made a mistake and we have the data to correct it. yes it would be nice to criticize and give a solution. We also choose them HA HA HA HA HA HA 
HA This WhatsApp "people don't know who offered me in April" said are all Rapid not a business? are rapid administrative requirements? BOOOOOR MAGIC LETTER. I did not move for 7 months in vain. In April, the prices are crazy. NOW? Why? I EVEN ALREADY COMPLETE DATA ON WHO'S OFFER ME TRADE RAPID FROM APRIL - JULY. One by one we fried. SINCE APRIL I RECEIVE MANY OFFER BOSS. I AM SILENT. IN THE PAST, 250-500 hundreds. Now that IDR 95,000 doesn't sell, what's the game? My number is a sensor, even though I'm a volunteer, do you want to trade rapid with me? How come it's so easy, Rapid is it sold freely? Now, it's only IDR 95,000 per pcs anyway. How many pes do these people sell rapidly? HAH? OPEN YOUR HEART TO ALLAAAAA.

\section{(22) "Perusahaannya usut!!!”}

(Investigae the company!!!)

Netizens mean in data (22) "take issue the elemnt" towards the use for business during a pandemic. Voiced about the side conducts rapid tests for all purposes. The effect is that netizens has been fooled by the sale of rapid tests.

Perlocutionary speech acts are responses by citizens in the form of representative by express anxiety, directive by waiting for clarity, commissive by committed, expressive by praying, suggestion, and declarative by taking issue.

\section{Content Responses in Netizens Illocutionary Acts}

Content Response is content that contains information about information through social media. Response content by type includes optimistic, pessimistic, and neutral contents.

\section{Optimistic Content}

According to Shapiro (in Ghufron \& Risnawati, 2011) states optimistic content is a belief in something positive in terms of having an attitude of hope for good things.

\section{Surrender Self}


Context Ministry of Health RI - \#Update of COVID-19 developments in Indonesia as of September 11, 2020 at 12.00 WIB. The number of confirmed positive cases \# COVID19 in Indonesia is 210,940 with 150,217 recovered 8,544 deaths. Stay alert with \#keepdistancing \#usemasker \#washhandswithsoap to break the chain of transmission of COVID-19. With us \#againscovid19.

(23) "Tiap hari pasti ada kematian karna itu takdir dari Allah. Siapapun tdak bisa menghentikan takdir kematian. Terus berdoa saja semoga keluarga kita di lidungi dari marabahaya dan di beri kesehatan selalu dan di mudahkan mencari rezki."

(Every day there must be death because it is a destiny from Allah. No one can stop the destiny of death. Just keep on praying that our families will be protected from danger and be given health and make it easier to find sustenance.)

Data (24), (25), and (26) are responses from netizens in the form of optimistic content. This optimistic content functions as an expression of prayingThe optimistic content of the data is seen from the substance consisting invitation

Based on the data above, the difference in optimistic content of the data (24) shows that netizens appeal which is indicated by the word "diharapkan" which is basically to reduce cases of infection. These data (25) serve as a detailed call to adhere to health protocols. Whereas data (26) returns the destiny of each individual that has been determined.

\section{Pessimistic Content}

Pessimistic Content is a belief that considers everything based on its basis as bad (Mangunhardjana, 1997).

\section{Distrust of the System}

Context Lambe_turah- A video of a patient's family was circulating with anger, because they did not accept the patient who was sentenced to the World Meningeal Hospital, because he was infected with the coronavirus (Covid-19).

(24) "Saya percaya COVID-19 itu ada, tapi saya tidak percaya bahwa data COVID-19 itu real adanya."

(I believe COVID-19 exists, but I don't believe that COVID-19 data is real.) 
Data (27), (28), and (29) are responses from netizens in the form of pessimistic content. This pessimistic content functions as a trust bias. The pessimistic content of the data can be seen from the substance consisting of the fact that there is a virus, falsification of verifying patients. Based on the data above, differences in the pessimistic content of the data (28) indicate beliefs about Covid-19, but not in the form of informed numerical data.

\section{Neutral Content}

Neutral content is an impartial assumption between one another.

\section{Free of Interest}

Context Kemenkes_ri- Hi \#Healthies. The government's efforts to control COVID-19 in anticipation of a surge in COVID-19 patients have been adequate, both from the human resources for health and the availability of patient isolation areas. The government continues to work hard to increase the cure rate for COVID-19 patients. The Minister of Health appealed to always adhere to health protocols and the participation of all parties, especially the role of the community and all sectors to discipline wearing masks, maintain distance and diligently wash hands with soap.

(25) "Berfikir positif tidak menyalahkan satu pihak atau pihak lain ttp semangat untuk pencegahan penularan covid 19 dan ttp bedoa, semoga bangsa kita Indonesia bangkit dan bisa maju smgttt bismillah."

(Thinking positively does not blame one party or the other but the enthusiasm for preventing the transmission of Covid 19 and still pray, hopefully our nation Indonesia will rise and be able to move forward as well as bismillah.)

Data (30) and (31) are responses from netizens in the form of neutral content. This neutral content functions as a form of conveying something without partiality. The neutral content of the data can be seen from the substance consisting of praying and carrying out worship. Based on the data above, the difference in data neutral content (31) shows that netizens do not corner any party by asking to pray to Allah SWT.

Content responses are response by citizens in the form of optimistic by surrender self, pessimistic by distrust of the system, and neutral by free of interest. 


\section{CONCLUSION}

Based on the results and discussion, it is determined that the response of netizens on Instagram and Facebook accounts towards the Covid-19 pandemic: First, citizens respond to new phenomena, both stratified in the form of loucotionary act of giving statements, illocutionary act of stating something, and perlocutionary act an effect on self. Second, the content of the response from the netizen. I. optimistic ii. pessimistic iii. neutral. This can be used as a benchmark if netizens have speed and social responsibility in communicating in mass media.

\section{REFERENCES}

Azizah, A. (2020). Analisis Tindak Tutur Caption dalam Instagram Ridwan Kamil. Parole (Jurnal Pendidikan Bahasa dan Sastra Indonesia), 3(3), 229-242.

Fakhriyah, F. N. (2020). Analisis Tindak Tutur dalam Novel Perempuan Berkalung Sorban Karya Abidah El Khalieqy. ARBITRER: Jurnal Pendidikan Bahasa dan Sastra Indonesia, 2(2), 273-282.

Fanani, F. (2020). Data Terkini Jumlah Korban Virus Corona di Indonesia. Retrieved from Merdeka. https://www.merdeka.com/.

Ghufron, M. N. \& Risnawita, S. R. (2010). Teori - teori Psikologi. Yogyakarta: Ar-ruz Media Group.

Inderasari, E., Achsani, F., \& Lestari, B. (2019). Bahasa Sarkasme Netizen dalam Komentar Akun Instragram "Lambe Turah”. Semantik, 8(1), 37-49.

Juwita, S. R., \& Purnamasasri, L. (2019). Pengembangan Tindak Tutur Ilokusi dalam Aktivitas Pembelajaran Dosen Pengampu Pelaksana Akademik Mata Kuliah Universitas (Pamu). Pujangga, 4(2), 16.

Kementerian Kesehatan RI. (2020). \#Update Perkembangan COVID-19 di Indonesia. Retrieved from Faecbook website https://www.facebook.com/KementerianKesehatanRI.

Khotimah, K. (2019). Tindak Tutur Ilokusi pada Percakapan Sehari-Hari Santriwati di Pondok Pesantren Mambaâ€тм Ul Hikam Burneh Bangkalan. PARAFRASE: Jurnal Kajian Kebahasaan \& Kesastraan, 19(1).

Lambe_turah. (2020). Beredar Video Seorang Keluarga Pasien yang Meluapkan Amarahnya Karena Tidak Terima Pasien Divonis Pihak Rumah Sakit Meninggal Dunia Karena 


\section{Journal of Pragmatics Research}

Vol. 2, No. 2, pp.177-200

E-ISSN: $2656-8020$

Website: http://e-journal.iainsalatiga.ac.id/index.php/jopr/index

Terinfeksi Virus Corona (Covid-19). Retrieved from Instagram website https://www.instagram.com/lambe_turah/?hl=en.

Lumbanrau, R. E. (2020). Covid-19 - Indonesia: Puncak Gelombang Pertama 'yang tak Berujung', Mengapa Protokol Kesehatan Sulit Dipatuhi? Retrieved from BBC News Indonesia website https://www.bbc.com/indonesia/topics/cjgn7k8yx4gt.

Mangunhardjana, A. (1997). Isme-Isme dalam Etika dari A- Z. Yogyakarta: Kanisius. 186-187. Meirisa, M., Rashid, Y., dan Murtadho, F. (2017). Tindak Tutur Ilokusi dalam Interaksi

Pembelajaran Bahasa Indonesia (Kajian Etnografi Komunikasi di SMA Ehipassiko School Bsd). Bahtera: Jurnal Pendidikan Bahasa dan Sastra, 16(2), 1-14.

Miranti, S. (2013). Tindak tutur guru dalam pengajaran Bahasa Indonesia di SLB C Bina Karya Singaraja. Jurnal Pendidikan Bahasa dan Sastra Indonesia Undiksha, 1(8).

Nasution, W. (2019). Analisis Tindak Tutur Ilokusi dalam Iklan Radio 99, 3 Toss Fm Merduati Banda Aceh. Metamorfosa Journal, 7(2), 269-283.

Prayitno, H. J. (2017). Studi Pragmatik. Surakarta: Muhammadiyah University Press.

Sekarsany, A., Darmayanti, N., \& Suparman, T. (2020). Tindak Tutur Ilokusi pada Proses Kelahiran dengan Teknik Hipnosis (Hypnobirthing). Metahumaniora, 10(1), 14-26.

Stambo, R., \& Ramadhan, S. (2019). Tindak tutur ilokusi pendakwah dalam program damai indonesiaku di TV One. BASINDO: jurnal kajian bahasa, sastra Indonesia, dan pembelajarannya, 3(2), 250-260.

Surdayanto. (2015). Metode dan Aneka Teknik Analisis Bahasa. Yogyakarta: Duta Wacana University.

Surianti, S., Akhir, M., \& Nojeng, A. (2019). Tindak Tutur Ilokusi Sebagai Media Penyampaian Pesan Sosial Pada Iklan Layanan Masyarakat. Celebes of Linguistics Journal, 1(2), 1118.

Tarigan, H. G. (2009). Pengajaran Pragmatik. Bandung: Angkasa Bandung.

Wahyuni, S. T., dan Retnowaty, R. (2018). Tindak Tutur Ilokusi pada Caption Akun Islami di Instagram. Jurnal Basataka (JBT), 1(2), 11-18.

Watie, Errika Dwi Setya. 2011. Komunikasi dan Media Sosial (Communications and Social Media). The Messenger, Vol. 3, No. 1, Hal. 69-75. 
Widyawati, N., \& Utomo, A. P. Y. (2020). Tindak Tutur Ilokusi dalam Video Podcast Deddy Corbuzier dan Najwa Shihab pada Media Sosial Youtube. Jurnal Ilmiah Telaah, 5(2), $18-27$. 